\title{
BRAND COMMUNITY AS A TOOL TO BUILD RELATIONSHIPS BETWEEN THE CONSUMER AND THE BRAND IN THE SERVICE MARKET - A THEORETICAL APPROACH
}

\section{MONIKA SKOREK}

The University of Warsaw, POLAND

e-mail: mskorek@wz.uw.edu.pl

RECEIVED

ACCEPTED

JEL

CLASSIFICATION

KEYWORDS

ABSTRACT
27 July 2017

15 December 2017

M31

brand community, service, brand equity, engagement, loyalty

This article is about using BCs to manage brand equity in the service market. Theoretical considerations include the specificity of market services and the essence of $B C$ formation. Various definitions of service are given. The service itself, however, is characterized by: immateriality, impermanence, inseparability of service and quality instability. The most popular model of service management by managers was shown. BC was presented from the modernism era through postmodernism up to the present. A set of variables influencing the emergence of the consumer group was shown. As a conclusion, the areas were shown in which a consumer group adhering to a given brand can be used to spread the brand image, increase loyalty, strengthen brand awareness, or better perceive its quality. $\mathrm{BC}$ is treated as a tool to manage the brand equity in the service market. The article recapitulation points to certain limitations. Its main imperfection is to present the problem only in theoretical terms, although the author sees the possibility of developing the problem based on research in the market of service goods.

\section{Introduction}

The everyday practice of marketing managers indicates a strong interest in the brand management process. The issue of the brand relationship with the consumer is often raised. Thus the importance of the "consumer-brandengagement" concept (Hollebeek, Glynn, Brodie, 2014) is growing , i.e. consumer involvement in the everyday life

of the brand. 
It argues that the nature of the interaction between brands and consumers needs to be more closely scrutinized, i.a. by exploring engagement. The issue seems interesting to analyze especially when relating the brand management and building customer relationship with the brand to the service market.

Brodie (2011) defines "customer engagement" as "mental state, which is based on interactive co-creation of customer experience (Kacprzak, Dziewanowska, Skorek, 2015) with the object, e.g. brand." The reasons underlying this change include the observed growing scientific recognition for today's rather active than passive roles and behavior of consumers in specific brand-related processes. However, despite initial assumptions, data on the consumer engagement dynamics are still rare, mainly due to the lack of adequate measurement and empirical confirmation.

Getting customers' trust in the service goods market is a key issue for marketers in building customer relationships. In the service market, the efficiency of competitive prices is small because consumers may find price reduction as a sign of deterioration in service quality, which in turn can lead to a loss of market competitiveness for the service provider. That is why competition in the service market essentially takes the non-price form, whereby service providers improve their product and refine its original version by adding new elements that bring additional benefits to consumers (Mongiało, 2007). Thus a lot of attention is paid to the quality of services. (Stoma, 2012, Bielawa, 2010; Hamrol, Mantura, 2008; Parasuraman, Zeithaml, Berry, 1988). Consumer perception of quality is understood as "the features or properties expected by the customer, (...) the degree of product or service excellence associated with additional fulfillment of the expectations associated with the product or service, compliance with customer requirements" (Roszak, 2014).

Another topic in the area of enhancing the relationship between the brand and the customer in the service market is the idea of educating the customer in the service process and thus building a long-term relationship with him (Eisingerich, Bell, 2008). This education includes technical as well as organizational and functional knowledge.

Non-price brand management policy in services doesn't need to be limited to improving and refining the product by improving service quality or customer education in the service process. The purpose of this article is to present another tool to build the brand and customer relationships in the service market, which is a BC This article describes the essence of services, the mechanism of functioning of a BC and the benefits to customers and brand owners coming from a group of its fans.

\section{The essence of services}

Today, the growth of the service sector decides about the economic growth in most countries in the world. This is evidenced by the growing share of services in GDP, labour absorption, investment, consumption and international trade (Czubała, 2015). The marketing concept of services clearly indicates that a service is a specific product subject to exchange transactions. The American Marketing Association defines a service as "separate and nonmaterial activity providing specific benefits that are not related to the sale of products or other services" (Styś, 2003). Grönroos (1990) emphasizes the service relational side, claiming that a service is "an action or a group of actions [...], taking place during the interactions between the customer and the service provider representative or the customer and the service provider's physical environment." Likewise the service is defined by Kotler (2005), Gilmore (2006), Czuba (2001) and Payne (1997). According to the aforementioned definitions, the basic feature to distinguish services from the physical products is their immateriality. Other service features, i.e. synchronicity of the provision and consumption process, heterogeneity and instability are derived from their immateriality (Garbarski, 
2001; Żurawik, 1999; Kotler, 2002; Czubała, Jonas, Smoleń, Wiktor, 2012). The specificity of services and especially their instability and immateriality require a different marketing approach than products. We should consider 3P, i.e. additional tools to be used in services, such as: people, physical evidence and process. The synchronicity of production and consumption generates a specific interaction between the service provider and the customer, which results in both the service provider and the consumer having an impact on the final form of the service.

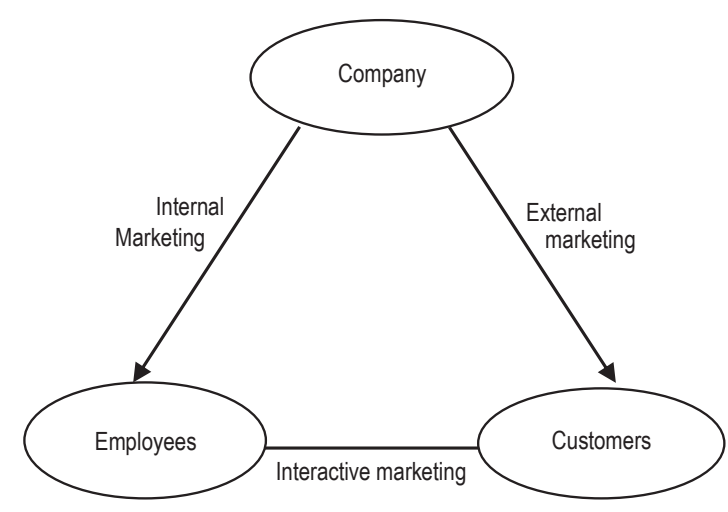

Figure 1. Service elements evaluated by the customer

Source: Kotler (2002), p. 714.

The consequence of the aforementioned relationship is understanding that building of the brand equity (Aaker, 1991) in the service market requires a different outlook on the classic tripartite division onto the external, internal, and interactive marketing. The last of the aforementioned areas allows us to manage the brand in services by considering the active role of the consumer or the whole consumer groups, which co-create or even co-manage the service brand.

\section{Theoretical reflections on the concept of BC}

From the beginning of this century up to now, BC. have been highly explored in marketing literature (StokburgerSauer, 2010). After the postmodern era and new forms of social relationships (Firat, Dhola, Venkatesh, 1995), a new need emerges for consumers characterized by the development of a sense of belonging to the group that places the formation of new social ties first among members of the grous. This is referred to as the "sense of community". This concept summarizes the sense of belonging to the community and the awareness of it (Heller, Aliii, 1984; Newbrough, Chavis, 1986 cited by Abdelkader, Bouslama, 2014).

Thus, postmodernist groups are known for their sense of community, which are now one of the psychological constructs being the subject of large number of studies. The interest in communities in the modern sense may be the result of seeing opportunities to strengthen the loyalty of the community members by the brand owners (McAlexander, Schouten, Koenig, 2002, pp. 38-54), influencing the behaviour of members with the introduction of a new product under the brand (Thompson, Sinha, 2008), opposition to competitor brands (Muniz, O'Guinn, Schau et al., 2009), and affect the intention to purchase (Liaw, 2011). 
BC. can also play an important role in creating relationships with the brand as their members are strongly associated with the brand and can become its advocates (Algesheimer, Dholakia, Herrmann, 2005; Andersen, 2005; Bagozzi, Dholakia, 2006,). As a result, BC. include people who may not be related to each other but only to a particular brand (Dubois, Westerhausen, 2011).

Muniz and O'Guinn (2001) list the following characteristics of brand communities:

- consciousness of kind,

- shared rituals and traditions),

- sense of moral responsilibity (see concepts' characteristics Skorek, 2017).

\section{Use of the BC in the service market}

The community characteristics described above, and the processes taking place in groups gathering around brands, have proven that emerging relationships in the community can be used to manage the brand in the service market.

To the previously described trio of relationships consisting of consumer and consumer and consumer and brand relations (Muniz, O'Guinn, 2001), another relationship was added (McAlexander et al., 2002). It was assumed that for the brand community member apart from relationships with other community members and with the brand itself, it is also important to have a relationship with the product he owns that's of a given brand, and with institutions which are owners of the brand he adores. The article authors also point out that the meaning of being a BC member comes not directly from the brand but from the experience acquired through engaging in a BC (McAlexander et al., 2002). Both types of community relationships centered around brands are illustrated below.

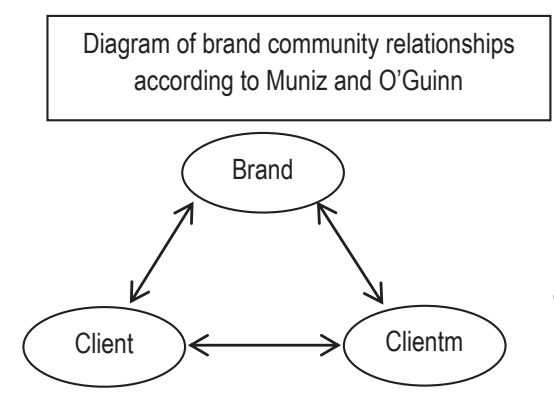

Diagram of brand community relationships by McAlexander, Schouten and Koening

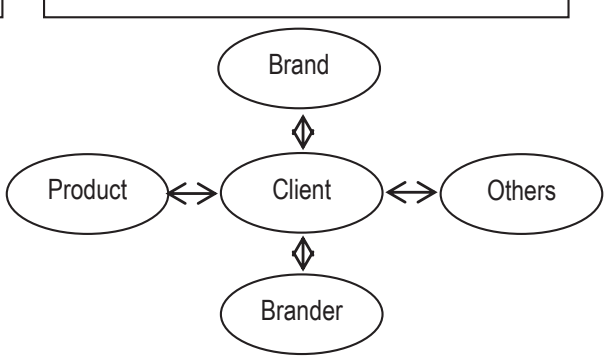

Figure 2. Relationships in the BC

Source: McAlexander et al. (2002), p. 39.

Although Muniz and O'Guinn have defined that BC is geographically unlimited, James H. McAlexander, John W. Schouten and Harold F. Koening state that the geographic concentration of a BC matters, if it's focused on one point, is scattered or exists only on the Internet (McAlexander et al., 2002).

The meanings of brand and branding have been evolving over the past several decades. This evolution is converging on a new conceptual logic, which views brand in terms of collaborative, value co-creation activities of 
firms and all of their stakeholders and brand value in terms of the stakeholders' collectively perceived value-in-use. (...) Marketing managers might benefit from investing resources in building strong brand relationships with all of their stakeholders and a service-dominant firm philosophy built around brand value co-creation (Merz, He, Vargo, 2009).

\section{Discussion}

Managing a brand in the service market is an art due to the quoted characteristics of the service product. The product itself will become a brand when it is noticed and accepted by consumers. Therefore, the capital and value will be built on consistency and genuine cooperation with consumers. Thus, consumers' influence on the brand and its management is essential.

As described above, BC. present some unique features and opportunities for marketing activities, and in particular for the brand management in the service market. For managers, it is important to identify from the beginning the relationship between the brand and consumers from a given community. From a management point of view, it is important to understand why and how consumers engage in the $\mathrm{BC}$ and what are its consequences. For the $\mathrm{BC}$ members, their relationship with the brand can be seen as a relationship with a company or as a simple interaction with other consumers with similar interests. In both cases, the marketer must identify the best ways to interact with the community without generating a sense of initiation. Thus marketers will learn how to organize or maintain BC, as "building and managing brand environments seems cost-effective and efficient" (Algesheimer et al., 2005). BC can create value for their members as well as for brand owners. To strategically manage brands, we should consider the relevant variables engaging consumers in the BC Service companies can "leverage positive group effects happening in communities that lead to compliance, community engagement, brand knowledge dissemination, or affecting brand loyalty" (Algesheimer et al., 2005). Engaged consumers show greater loyalty, satisfaction, consolidation, connectivity, emotional bonding, trust and commitment "(Brodie, 2011) Most of these elements contribute to the formation of brand equity.

Experienced managers will confirm that brand equity can be built by creating appropriate structures of brand knowledge based on conversations with relevant consumers. These include brand community members. Consumers' engagement translates into brand awareness, so the presence in BC is based both on passion and brand awareness. BC becomes a vehicle through which consumers have the opportunity to share their opinions, thoughts, feelings and experiences, and to exchange brand information based on the subjective brand knowledge. Brands are built on the basis of consumer opinion and experience.

This is why the concept of co-management is proposed stating that "customers are active co-creators of brand value" (Cherif, Miled, 2013). Algesheimer, Dholakia, Herrmann (2005) believe that "BC offer a new, effective, and viral approach to brand building in the current marketing environment." In order to enhance the potential of these communities, it is recommended to identify opinion leaders and opinion-makers in each brand community. Influential community members can significantly influence the views of other community members.

McAlexander, Koenig, Schouten (2006) conducted a study on the market of higher education services. It showed that this area can also evoke and benefit from the valued qualities of brand community, that are associated with these brands and products. This study shows, that integration in a brand community in higher education can contribute to such valued behaviors as donations, college referrals, engagement in alumni groups, and participation in continuing education. These are the outcomes, that are sought by those professionals, who share the responsibilities of marketing and advancement in higher education (McAlexander et al., 2006). 
The most important conclusion of this study is the demonstration of strategic value for educational service managers (McAlexander et al., 2006):

- utilizing the synergy effect resulting from managing of a group rather than of individual clients gives better possibilities for brand management and stronger commitment to the brand,

- the use of knowledge and cooperation of university staff with students gives the opportunity to strengthen relationship with the brand,

- reaping the benefits resulting from cooperation with alumni associations to maintain relationship with the brand,

- making the managers aware that they should start building relationships with students right from the first contact in classes and not after the students graduate.

\section{Conclusions and limitations}

This study is of a theoretical nature. It considered the specificity of the service market and presented the overview of issues related to the BC It also showed the concept essence, its characteristics, community features and factors contributing to the formation and organization of the $\mathrm{BC}$ In the article two areas were linked to show how to use BC to build customer relationships with the brand in the service market. The only limitation of the text is adopting only a theoretical perspective. In the future the presented theoretical considerations should be applied in specific market situations and a study should be conducted based on specific brands in the service market. Perhaps we should think of building a model to analyze the mechanism of maintaining the existing BC. It is expected that the increasing level of consumer engagement with the brand will promote better performance, including increased sales, lower costs, increased brand recommendations, enhanced consumer input into the common product development process, enhanced co-creation and improved profitability. Consequently, engagement will become a key censor to evaluate the brand performance in the service market.

\section{References}

Aaker, D.A. (1991). Managing Brand Equity. New York: The Free Press.

Abdelkader, S., Bouslama, N. (2014). The Role of Sense of Community in Mediation between Positive Emotions and Attitudes toward Brand and Message. Journal of Marketing Research \& Case Studies, 17. DOI: 10.5171/2014.349677.

Algesheimer, R., Dholakia, U.M., Herrmann, A. (2005). The social influence of brand community: Evidence from European car clubs. Journal of Marketing, 3 (69), 19-34.

Andersen, S.H. (2005). Relationship marketing and brand involvement of professionals through web-enhance brand communities: The case of Coloplast. Industrial Marketing Management, 1 (34), 39-51.

Bagozzi, R.S., Dholakia, U.M. (2006). Antecedents and purchase consequences of customer participation in small group brand communities. International Journal of Research in Marketing, 1 (23), 45-61.

Bielawa, A. (2010). Miejsce jakości w usługach. Zeszyty Naukowe Uniwersytetu Szczecińskiego. Przedsiębiorstwa w procesie zmian. Studia i Prace Wydziału Nauk Ekonomicznych i Zarządzania, 17, 255-263.

Brodie, R.J., llic, A., Juric, B., Hollebeek, L. (2011). Consumer engagement in a virtual brand community: An exploratory analysis. Journal of Business Research, 1 (66), 105-114, DOI:10.1016/j.jbusres.2011.07.029.

Cherif, H., Miled, B. (2013). Are Brand Communities Influencing Brands through Co-creation? A Cross-National Example of the Brand AXE: In France and in Tunisia. International Business Research, 6 (9), 14-29.

Czuba, M. (2001). Marketing usług. Teoria i praktyka. Katowice: Wydawnictwo TARA.

Czubała, A. (2015). Innowacje w sektorze usług w Polsce. Zeszyty Naukowe Małopolskiej Wyższej Szkoły Ekonomicznej w Tarnowie, $1(26), 35-45$. 
Czubała, A., Jonas T., Smoleń J., Wiktor W. (2012). Marketing usług. Warszawa: Wydawnictwo Wolters Kluwer Polska.

Dubois, T., Westerhausen, U. (2011). Brand loyalty creation within online brand communities. Copenhagen: Copenhagen Business School.

Eisingerich, A.B., Bell, S.J. (2008). Perceived Service Quality and Customer Trust. Does Enhancing Customers' Service Knowledge Matter? Journal of Service Research, 3 (10), 256-268.

Firat, A.F., Dholakia, N., Venkatesh, A. (1995). Marketing in a postmodern world. European Journal of Marketing, 1 (29), 40-56.

Garbarski, L. (2001). Marketing. Warszawa: PWE.

Gilmore, A. (2006). Usługi. Marketing i zarządzanie. Warszawa: PWE.

Grönroos, C. (1990). Service management and marketing, Managing the moments of thruth in servicecompetition. Massachusetts: Lexington Books.

Hamrol, A., Mantura, W. (2008). Zarządzanie jakością. Teoria i praktyka. Warszawa: Wydawnictwo Naukowe PWN.

Hollebeek, L.D., Glynn, M.S., Brodie, R.J. (2014). Consumer Brand Engagement in Social Media: Conceptualization, Scale Development and Validation. Journal of Interactive Marketing, 28.

Kacprzak, A., Dziewanowska, K., Skorek, M. (2015). Gospodarka doświadczeń. Perspektywa polskiego konsumenta. Warszawa: Wydawnictwo Naukowe PWN.

Kotler, P. (2002). Marketing podręcznik europejski. Warszawa: PWE.

Kotler P. (2005). Marketing. Poznań: Dom Wydawniczy REBIS.

Liaw, G.F. (2011). A Study on the Influence of Consumers' Participation in a Brand Community on Purchase Intention. Journal of International Management Studies, 1 (6). Retrieved from: http://www.jimsjournal.org/pi.html.

McAlexander, J.H., Koenig H.F., Schouten J.W. (2006). Building Relationships of Brand Community in Higher Education: A Strategic Framework for University Advancement. International Journal of Educational Advancement, 2 (6), 107-118.

McAlexander, J., Schouten, J., Koenig, H. (2002). Building Brand Community. Journal of Marketing, 66, 38-54.

Merz, M.A., He, Y., Vargo, S.L. (2009). The evolving brand logic: a service-dominant logic perspective. Journal of the Academy of Marketing Science, 37, 328-344.

Mongiało, D. (2007). Czynniki wpływające na strukturę rynku usług. Gospodarka Narodowa, 3, 85-98.

Muniz, A., O'Guinn, T. (2001). Brand Community. Journal of Consumer Research, 4 (27), 12-432.

Parasuraman, A., Valarie, A., Zeithaml, L., Berry, L. (1988). SERVQUAL: A Multiple-Item Scale for Measuring Consumer Perception of Service Quality. Journal of Retailing, 1 (64), 12-40.

Payne, A. (1997). Marketing usług. Warszawa: PWE.

Roszak, M. (2014). Zarządzanie jakością w praktyce inżynierskiej. Open Access Library, 1 (31), 103-145.

Schau, H.J., Muniz Jr., A.M., Arnould, E.J. (2009). How Brand Community Practices Create Value. Journal of Marketing, 5 (73), $30-51$.

Skorek, M., (2017). Natura wspólnoty wokół marki w świetle badań własnych. Marketing i Rynek, 7.

Stokburger-Sauer, N. (2010). Brand Community: Drivers and Outcomes. Psychology \& Marketing, 4 (27), 347-368. DOI: 10.1002/ mar.20335.

Stoma, M. (2012). Modele i metody pomiaru jakości usług. Lublin: Lubelski Dom Medialny.

Styś, A. (2003). Marketing usług. Warszawa: PWE.

Thompson, S.A., Sinha, R.K. (2008). Brand Communities and New Product Adoption: The Influence and Limits of Oppositional Loyalty. Journal of Marketing, 6 (72), 65-80.

Żurawik, B. (1999). Marketing usług finansowych. Warszawa: Wydawnictwo Naukowe PWN.

Cite this anticle aS: Skorek, M. (2018). Brand community as a tool to build relationships between the consumer and the brand in the service market - a theoretical approach. European Journal of Service Management, 2 (26), 217-223. DOI: 10.18276/ejsm.2018.26-27. 